\title{
The Puritans in Early American Society and the Premises of Religious Fundamentalism
}

\section{Article History}

Received: 19 March, 2021

Revised: 09 April, 2021

Accepted: 15 April, 2021

Published: 20 April, 2021

Copyright $@ 2021$ Noble Academic Publisher \& Author

\author{
Birane Sene* \\ American and Caribbean Studies Laboratory Cheikh Anta Diop University \\ of Dakar, Senegal
}

\begin{abstract}
Puritanism is historically a form of Protestantism, resulting from the movement of John Calvin affirmed in England, from the 1560s in reaction against official Anglicanism considered too close to idolatry. Puritans will leave England where they were persecuted and settle in the East of the United States later known as New England. This puritan community will serve as a model of a Protestant state based on religious principles. The rigor of the Calvinist doctrine determined social relations and guided the destiny of handpicked people for their moral rectitude. The principles that governed this Puritan society were already laying the foundations for a theocracy whose imprints are still visible in today's American society. The puritans were pretending to be the light that should shine above the world and enlighten it with its values, and on this basis, they excluded any relationship of equality with others. Despite this theocratic ideal, the Protestant identity will gradually fade in favor of a secular state with a religious diversity and pluralism.
\end{abstract}

Keywords: America, Democracy, Extremism, Fundamentalism Puritanism, Theocracy.

\section{Introduction}

The United States of America was founded both on the quest for profit and on the basis of a religious mission. During its formation as a nation, the first settlers called puritans embraced a model which was based on a separatist principle that wanted to break with certain religious practices ongoing in England. Puritanism can be defined as a conception of the Christian faith developed in England by a community of radical Protestants after the Reformation of the church in the $16^{\text {th }}$ century. Some people would define the movement as a political theory and a religious doctrine at the same time .Once they arrived in America, the Puritans started to create what they called "A City upon a Hill", that is to say, a religious model supposed to ensure the redemption of a corrupted old world. This world or society will be based on an exceptionalism which makes of puritans "Chosen People" who have left the corrupted England to settle in their new granted land by providence.

The religious history of the United States is intertwined with the arrival of these Puritans in the New World. These latter, being seen as religious dissidents, would shape what they think the American society should look like. The religious spirit that animated these pilgrims ended up winning over mentalities and making God a permanent reference. Such an ideology is closer to a theocracy in which citizens run the risk of being governed by fundamentalists. Fundamentalists of all religions have in common the fact that they reject the replacement of the sacred by secularism and rationalism. They oppose ecumenism, pluralism and religious relativism, as well as the liberalization, phenomena sometimes put together under the term modernity or modernism. More generally, fundamentalism is, for any religion, the tendency of some of its followers to return to what is considered fundamental or original.

This attitude was the frame of mind of the first settlers of America. If the country is regarded today as a place of religious diversity and pluralism, it's because there is a shift from the first puritan society. This article aims at bringing light in this old puritan society where the seed had already been planted to transform this country into a theocracy. The first part of this analysis is devoted the ideology of setting a theocratic state in America. The second part focuses on fundamentalist practices that could have changed the democratic ideal prevailing in America today. 


\section{The Puritan Ideology and the Reported Story of a Failed Theocracy}

At the beginning of the 17th century, North America was still a virgin continent for Europeans, apart from a few attempts of settlements. Everything was going to change with the reigns of the English kings Jacques I (1603-1625) and Charles I (1625-1649), when the religious intransigence of these two sovereigns, determined champions of Anglicanism, led to the emigration groups of Puritan dissidents, eager both to live their faith freely and to found, a the New World, a "New Jerusalem", in other words, communities living according to the law of God as stated by the great reformers like John Calvin. As a result of this persecution, many people left Europe in boats to reach the New World in order to freely live their faith according to biblical principles.

The most symbolic date of this exodus is that of December 21, 1620, when a group of English Puritans, later known as the "Pilgrim Fathers," and who had traveled aboard the "Mayflower "Arrives at Cape Cod in what is known today as the State of Massachusetts. During the crossing, these pilgrims were bound by a contract, known as the "Mayflower Compact". This contract was to become the constitution of the new colony with strict observance of the Calvinist faith and cult, that is to say, intense community life and unfailing social and moral discipline.

Puritan religious motivation is therefore at the very origin of these first settlements in America. These different groups are initially independent from one another. It is only later that they will come closer to each other, and learn to live together. Gradually thirteen British colonies were established on the East Coast of North America. (Virginia, Massachusetts, New Hampshire, Maryland, Connecticut, Rhode Island, Delaware, North Carolina, South Carolina, New Jersey, New York Pennsylvania, Georgia).

Once in the New World, the "City upon a Hill" becomes the very symbol of the Puritans' will to fulfill the scriptures by reactivating the story of a new man in a new world. This New World then becomes the fantastical place of new beginnings. The Pilgrims identify with Israel, England becomes Egypt, King James the Pharaoh, the Atlantic the Red Sea, New England the "New Canaan." The first emigrants from Europe hasten to put on the new land the mantle of utopia where God is at the basis of everything. John Winthrop makes of the future city a model for humanity. His sermon would be seen later as a precursor of the "Manifest Destiny".

We must always think that we will be a City upon a Hill. The eyes of all people are upon us; so that if we should fail, before our God, in the mission which we have undertaken, and if he thus withdraws his support from us, we will become the reproach of the whole world, we will allow our enemies to denounce the ways of God (Winthrop, 2009).

Among the major goals of the Puritans was, building a prosperous country that would dominate all others, thereby proving their status as "Chosen People" of God, and also building a paradise in their Promised Land. The terminology of City upon a Hill, referring to America, is evocative of the desire and the wish to found a nation which would be superior to all the others, because it is closer to the Almighty. The description made by the new settlers shows that this country is a new Eden which should be inhabited accordingly by new people devoid of stains. This is the image painted by Thomas Morton to describe their dwelling place.

This country lies within the limits of the golden mean; it is very suitable for habitation and reproduction, since Almighty God, the Great Creator, has placed it in the area called temperate. It is therefore the most suitable for the dwelling and reproduction of our English nation. [...] The softness of the air, the fertility of the soil, the small number of savages, the conveniences of the sea [...] show that this country is in no way inferior to the Canaan of Israel and that we can, on the contrary, compare it to it in all points. (Morton, 1637). The logic of an America occupying the first place on the world chessboard, as City upon a Hill, was clearly found in the prospect of creating the country of the "Chosen People" A land of God which should not be subjected to the diktat of others. Hence the idea of valuing the high level of education and wealth that were symbols of the election to the American Eden. Harvard University located in Cambridge, Massachusetts was founded on October 28, 1636 by the Puritans to make sure that they have a high level of education. This university is one of the eight oldest and most famous higher education institutions in the United States. So the "Chosen People" were, in other words, the very well educated Puritans or those who had significant capital and who watched over the good practice of religion, by decent behavior and the enterprise of eliminating enemies.

A new idea of conquest will be born with this conception that God has shown the way, but it is up to the pioneers to clear the Promised Land and use it to meet material needs. As work is imperative, it goes without saying that idleness is prohibited. Part of the New Jerusalem will therefore be the product of labor. So while waiting to be reborn far from European hell, the settlers consider themselves to be on the verge of fulfilling the final stage of history. Like Joshua who fought in the Old Testament against the 
Canaanite tribes to impose himself, the settlers in turn will slaughter the Native American tribes to build their "empire". The concept of Manifest Destiny" which is "America's right to occupy the entire continent granted by Providence to allow the free progress of our millions of inhabitants and their descendants" (Guelin, 2004) is used to drive many people out and occupy the land.

To justify the legitimacy of the Puritans over others, John Winthrop said: "If God wasn't happy to see us occupy these lands, watch, why would He drive out the natives?" And why does he make room for us, reducing their numbers as ours grows?" (Kosmin and Lachman, 1993). These native Indians to the eyes of the puritans were "Unchosen People", savages which have to be eliminated to make space for" Chosen People." This vision of a radiant society in the New World envisions exemplary human development. A fertile America without limit and free from any clerical tradition and class distinction, everything seems possible, even Paradise. Virginia is described by Thomas Harriot as the "paradise of the world". There are many examples of this enlightenment facing the garden of the world where milk and honey flow to take up the Bible.

George Alsop presents Maryland "Land of Mary" in reference to the Virgin Mary as the only place that appears to be "Heaven on earth". Others are discovering the "future Eden" in Georgia: "that promised Canaan", which was appointed by God's own choice to bless the work of a favorite people." For Edward Johnson, Massachusetts is the place "where the Lord will create a new heaven and a new earth." (Marter, 1995). So there was no doubt that the Puritans were founding a theocracy by swimming in biblical memories to establish the parallel between this New World, Paradise and the Promised Land. In 1647, John Eliot announced the dawn, if not the sunrise of the gospel in New England. Cotton Mather meanwhile prophesied in his utopia Theopolis Americana, in these terms the restoration of millennial paradise in America. "The new birth must come through a return to the" purity of the original Church. The first age was the Golden Age. To come back to that age, the man has to become a Protestant, and I can add a Puritan" (Marter, 1995).

Thus, the signatories of the "Mayflower Compact" undertake to create a political body to establish a colony to the glory of the Lord. This alliance commits them to prepare and obey laws. The consent sought is not that of equal and free men in a democratic society, in the current sense of the term. Beranger declared about communal life principles governing this puritan society that: "Consent to be governed and to obey laws consecrating the inequality of the Creature and his subordination to the Word. If there is a partnership contract, it is a Calvinist contract" (Beranger, 1981).

Pilgrim Fathers with their concern for a social organization which reflects their religious beliefs will establish amendments which will later become the constitutional basis of these new states. The guiding principles of this Puritan society can be found in some of their amendments among which we can quote three. The "Depravity Man" which consists in recognizing the omnipotence of God and the sinful nature of man. According to this principle man is fundamentally bad and need to be punished. Another principle related to the Calvinist vision of society is "Limited Atonement" which means that Jesus did not die to save everyone but only a few worthy people. Another principle called "Irresistible Grace" proclaims that God saves or curses whoever he wants.

The example of these three principles among others demonstrates that Puritan theology was therefore a version of Calvinism. This affirms the fundamentally sinful character of the human beings, but also declares that God has judged certain men worthy of being saved because of the virtue of Christ. In the Protestant Catechism Antoine NOUIS affirms: "No one here below can be certain of his eternal destiny. Nevertheless, the experience of conversion signals that the person is one of the elected, for the soul touched by the Holy Spirit turns from sin to holiness"(Nouis, 1997).

The Puritan spiritual life is therefore marked by self-discipline and introspection. Although it is impossible to verify whether such spiritual constraints were true proofs of holiness. The belief that they had been chosen by God, strengthened the Puritans in their struggle against what they considered to be the vagaries of society and the infidelity of the Church. It enabled them to endure the sufferings they encountered when seeking to found a Christian community in the New World. It is obvious that the Pilgrims therefore did not bring religious freedom from the beginning. They sought their own freedom of belief first and did not necessarily want to found a community opens to anyone. In the 17 th century, the words tolerance and democracy were far from being the main concerns.

The theological vision affirms the absolute and arbitrary monarchy of God. This natural law has implications for economic life. The capitalist market economy fits easily into God's plan. For Calvinists, wealth is a divine blessing, poverty condemnable. Wealth and individual success are determined by divine election. As Calvin has said it: "The providential order establishes a natural inequality which must be corrected through the practice of charity. With this in mind, theology strengthens social stability and makes the idea of conflict unlikely to happen" (Lapouge, 1973). 
This Calvinist frame of mind in handling the destiny of a society was the corner stone of the foundation of new puritan states in the East of the United States. The Puritans stick to principles and doctrine whose essence rests on the intense commitment of its members to a morality, a form of worship, and a civil society that strictly conforms to the commandments of God. The changes in American society transformed the Puritans' project of theocratic state into a secular state, removing the prospect of a religious fundamentalism they were beginning to shape.

\section{The Premises of Religious Fundamentalism in the Process of Nation Building}

The Pilgrims Fathers had shown the way that freedom lies in dissent, but they did not foresee the chain of dissension that will gradually forge America to end their theocratic project. Religious fundamentalism was prevailing even if they had left England basically to enjoy religious freedom. The "City of God", yet erected by the persecuted, is not paradoxically that of complete freedom of expression. Rebellion wills first breakout from one of them called Thomas Morton who wrote The New English Canaan a book in which he was criticizing puritan customs. He was denouncing the puritan government in the colonies and their policies of land enclosure against the native population. He will be put in jail by puritans but he will show the way to others contentions related to fundamentalist principles which are used to run communities under puritans' governance. Some other exclusion will be needed for religious freedom to stand in this New World where dissident voices are banished.

The life of the Puritans is thus organized according to dogmatic principles which will later endorse all kinds of excesses and the legitimation of a feeling of inferiority orchestrated by this community which believes to be superior to others or invested with a divine mission. Radical currents will push to the extreme the methods of this movement which bore the seeds of religious fundamentalism. The obligations to attend religious services under penalty of sanctions and the exclusion of non-Protestants from citizenship are all factors that hinted at the building of a future theocratic state with latent fundamentalism. Along with the Puritans' fundamentalism, Louis Mendy has said in his book that 'the ordinance of 1631 stipulated that only members of the Church were citizens. The revolt was seen as a religious crime as well as a secular one. This theocracy was based on rigorous ethics" (Mendy, 2015). God being a God of order, pleasure and especially excess were banished. Austerity was enforced, even in female attire. The theological vision affirmed the absolute and arbitrary monarchy of God. The use of alcohol was forbidden as well as public festivities of that kind.

Thus the first American temperance society was founded in 1826 in the state of Maine which was the first to establish the limitation and control of the use of alcoholic beverages in 1851, followed by 12 others. They were called the Dry States as opposed to the others where alcohol flowed freely: the Wet States (Mendy, 2015).

The temptation of an individual allegorical interpretation of the scriptures which gave rise to such extremism has contributed to the exclusion or even to the stigmatization of certain minorities who have been marginalized for religious reasons. To understand this, we must remember that the first settlers who founded from 1620 what would become the United States were dissidents fleeing the English monarchy closely linked to the Anglican Church. Among them, the Puritans, who founded New England, were not supporters of religious freedom at all. Crimes were judged in reference to the book of Exodus and some like murder, treason, adultery, blasphemy or witchcraft were punishable by death because Moses would have ordered it. Pierre Chaunu revealed that religious fundamentalism saying:

In a society where religion and law were confused and where the magistrate was the priest's agent, it is not surprising that the maintenance of morality was included in the powers of civil authority and to constrain the individual to remain virtuous the most meticulous and cruel regulations were resorted to (Chaunu, 1991).

That was how the so called saints performed political, civil, legal and religious functions. They had then granted themselves a sort of divine power of attorney which writers like Nathaniel Hawthorne strongly denounce in writings such as The Scarlet Letter. Not very tolerant, the puritans engaged in extremist enterprises, such as the "witch hunts" which shook the small town of Salem and the entire colony in 1692. The Puritan Code excluded any contact on an equal footing with indigenous populations and those outside. Even if the freedom of worship has now become a reality, with the multiplicity of denominations, the descendants of the Puritan churches were defining themselves as the holders of the light of the world and were convinced that the only way to a healthy life was theirs. A state in which only members of the Church were considered citizens was nothing more than the embodiment of religious extremism as we know it today. 
Sectarianism took hold in the colony of Plymouth where the Anabaptists and Quakers were attacked and attendance at church service was made compulsory. This desire for exclusion had considerable consequences not only on the religious level but also on the social level. The Puritans wanted to have a way of life in keeping with religious principles so much so that they have created religious intolerance. Accustomed to an allegorical analysis of the Bible, they readily considered that everything that happened to them in their daily existence should be the object of an interpretation whether individual or collective. In some cases, this interpretation was, in fact, a search for signs of election. George Marsden stated that "Over generations, therefore, individuals have come to consider, that everything that happened positive or negative in life, and not just in the religious realm, was a sign that has a religious meaning" (Marsden, 1980). Thus, social success was considered a sign, perhaps not of election in the sense of the word, but at least of virtue and moral value, hence the importance of the display of signs of social success, starting with wealth.

The idea that wealth is a sign of divine election and poverty a curse crushed many people's effort to fight for their dignity. This puritan ideology has plunged for a long time a great number of people into a fated and unjustified resignation. Starting from nothing to reach the top is, however, the very basis of the "American Dream" materialized by the capitalist ideology which advocates success through once own efforts. Therefore, to persuade people that they are condemned in advance by making them believe that their poverty is nothing more than God's damnation is maintaining them in despair. In such a country, poverty was blamed and interpreted as laziness. This Puritan conception of poverty is rather the result of their religious interpretation through which they distinguish themselves from others as chosen by God and impose on the others a model of subjugation. This social classification is a serious attack on human dignity but was in keeping with John Winthrop theology as he said:

Almighty God in his most holy and wise providence has decided the condition of man in such a way that at all times, some must be rich, some poor, some more in high positions and eminent in power and in dignity, other small and in a state of submission (Winthrop, 2009).

This frame of mind has given rise to difficult or even conflicting social relationships within this multiracial society. Where misery and opulence come together because of an unbalanced social organization it would be unfair to justify it by the fact that rich people are chosen and poor people are cursed by god. The Puritans believe that the only way of salvation from God by whom they were anointed members, but this status also elevated them above others. Even after the adoption of the new constitution, which in its first amendment stipulates the equality of all men, the sense of superiority inherited from the Puritan past has left many scars in the conscience of many minorities.

Intolerance was going on and the integration of non-Protestants into this society was not easy. These Puritans, considering all other religious beliefs to be false, tolerated no disagreement and, therefore, drove out dissenters, tortured and condemned Quakers to death as heretics. This extremism is a result of the unfair treatment of minorities by puritans.

Elsewhere in colonial America, soon after Maryland was founded as a Catholic colony, Catholic leaders were returned to England in chains, and the practice of Catholicism was suppressed in Maryland for most of the 18th century. The Catholic Mass was declared illegal in South Carolina until 1790 and, in North Carolina, Jews could not hold public office until 1868 (Hasson, 2005 ).

Episodes of that kind are numerous and denote the clear will of certain Puritan groups to jeopardize religious freedom. If religious pluralism is a reality today, it is because a transition has been made. To move away from this very rigid puritan model towards a more flexible and less restrictive system. With non-puritan immigrants, this doctrine will gradually be diluted in American culture. From this long history of competition between labels of limited tolerance and genuine intolerance, the Founding Fathers took some important steps towards a broader legal basis for religious freedom.

\section{Conclusion}

The Puritans who left England, some for religious reasons, the others for economic reasons, had come together during the crossing of the Atlantic Ocean that had brought them together. To these early Puritan settlers, America was the Promised Land like that of the Hebrews, a kind of paradise on earth, and to enter it was the result of predestination. This is how the leaders of these Puritans gave themselves the title of "Chosen People" of God and therefore had to protect and defend their paradise against the supposed enemies of their Creator and their religion, with all means they have. These so-called enemies were naturally called disciples of Satan: which reminds us about a same rhetoric of the "Axis of Evil" used in the beginning of the $21^{\text {st }}$ century. 
The first contact of these immigrants with American soil was not easy because they consider themselves superior to the others and they did not recognize any other religion as true that their own. This messianic feeling which has resulted to a religious fundamentalist is still perceptible in today's political speeches to recall the role of guide that the United States must play. It is clear that with all these adventures, we were far from imagining the United States living one day in a society with religious diversity.

\section{References}

Beranger, P. J. (1981). Histoire des Idées aux USA, Paris, PUF.

Chaunu, P. (1991). L'Aventure de la Reforme : Le Monde de Jean Calvin, Bruxelles, Editions Complexe.

Guelin, N. (2004). Etats-Unis : L'imposture messianique. Genèse et sources, Paris, L'Harmattan.

Hasson, K. (2005 ). The Right to be wrong, New York, Ponce.

Kosmin, B. and Lachman, S. (1993). One Nation Under God, NYC, ed. Harmony Books.

Lapouge, G. (1973). Utopie et civilisation, Paris, Weber.

Marsden, G. M. (1980). Fundamentalism and American Culture; the Shaping of Twentieth-Century Evangelicalism, 1870-1925, Oxford, Oxford University Press.

Marter, C. (1995). Theopolis Americana : Histoire du Paradis, Mille ans de bonheur, vol. II, Paris, Fayard.

Mendy, L. (2015). Survivances de la doctrine du puritanisme dans l'Amérique moderne, Paris, L'Harmattan.

Morton, T. (1637). New English Canaan or New Canaan, Amsterdam, Stam.

Nouis, A. (1997). Un Catéchisme Protestant, Lyon, Réveil publication.

Winthrop, J. (2009). A Modell of Christian Charity, New Edition, New York, Evergreen Review. 